Rocznik Andragogiczny

\title{
Marion Fleige, Wiltrud Gieseke, Steffi Robak, Kulturelle Erwachsenenbildung. Strukturen - Partizipationsformen - Domänen, Bertelsmann Verlag, Bielefeld 2015, ss. 210
}

Recenzowana monografia, której tytuł w tłumaczeniu brzmi „Edukacja kulturalna dorosłych. Struktury - formy uczestnictwa - dziedziny", to znacząca pozycja w obszarze refleksji andragogicznej, m.in. ze względu na to, iż wciąż zdecydowanie brakuje naukowych opracowań zarówno o charakterze empirycznym, jak i teoretycznym, zajmujących się tą właśnie tematyką. Edukacja kulturalna dorosłych zdaje się sytuować na marginesie zainteresowania nie tylko badaczy, ale i polityki. Także autorki wskazują, że choć w ostatnich latach edukacja kulturalna jest obecna w dyskursie politycznym i społecznym, organizuje się na ten temat sporo seminariów i konferencji, o zainteresowanie nią zabiegają także organizacje międzynarodowe, jak choćby UNESCO, a polityka oświatowa wspiera edukację kulturalną poprzez programy dotacyjne, to jednak te impulsy i przedsięwzięcia nie obejmują edukacji kulturalnej dorosłych. „W sferze polityki oświatowej zdaje się dominować pogląd, że w tym obszarze wystarcza edukacja szkolna i pozaszkolna. Nie zawsze wprost formułowane przekonanie zakłada, że jeśli człowiek w szkole w odpowiednim stopniu rozwinie kreatywność i kompetencje kulturalne, to na późniejszych etapach życia będą one rozwijały się dalej samoczynnie", stwierdzają Marion Fleige, Wiltrud Gieseke i Steffi Robak (s. 12).

Badaczki próbują wzmocnić zainteresowanie edukacją kulturalną dorosłych oraz ugruntować jej pozycję, opracowując jej teoretyczne ramy i odwołując się w tym celu do danych empirycznych oraz sięgając do myśli z obszaru pedagogiki, kulturoznawstwa, filozofii, socjologii, psychologii społecznej. Praca jest kontynuacją i owocem dotychczasowej aktywności naukowej autorek, związanej z obszarem andragogiki, w obrębie której istotne pole problemowe stanowi właśnie edukacja kulturalna dorosłych. W książce wykorzystano dane pozyskane w ramach projektów badawczych realizowanych przez autorki i ich współpracowników na przestrzeni w ostatnich kilkunastu 
lat, a także wypracowane na ich podstawie podejścia teoretyczne. Zostały tu więc spożytkowane wyniki polsko-niemieckich komparatystycznych badań edukacji kulturalnej dorosłych z lat 2000-2003, a także badań nawiązujących do nich, realizowanych w późniejszych latach w ramach trzech projektów dotyczących: edukacji międzykulturowej, treści pozaformalnej edukacji kulturalnej dorosłych i młodzieży oraz oferty uczenia się dorosłych w muzeach. Poza tym w książce odwołano się również do wyników badań nad edukacją kulturalną w uniwersytetach ludowych oraz nad ofertą doskonalenia zawodowego dla artystów i twórców kultury. Fundament rozważań w monografii stanowi zaś koncepcja trzech portali uczestnictwa/portali edukacji kulturalnej dorosłych autorstwa Wiltrud Gieseke, będąca owocem pierwszego z wymienionych przedsięwzięć badawczych - projektu polsko-niemieckiego. W tym ujęciu oferty edukacji kulturalnej pojmowane są jako portale dostępu do edukacji i kultury. Według Wiltrud Gieseke jest to portal systematyczno-receptywny (systematisch-rezeptiv), portal własnej aktywności twórczej (selbsttätig-kreativ) i rozumiejąco-komunikacyjny, w wąskim rozumieniu interkulturowy (verstehend-kommunikativ, interkulturell). W recenzowanej pozycji zaproponowano kolejny - transkulturowy.

Jak wskazują autorki, cel omawianej monografii to wyodrębnienie i opracowanie pojęcia „edukacji kulturalnej dorosłych”; zaprezentowanie obszaru edukacji kulturalnej dorosłych, jej treści, form, uwarunkowań organizacyjnych oraz instytucjonalnych; sformułowanie aktualnych pytań dotyczących jej rozwoju; opisanie zróżnicowanego pola edukacji kulturalnej, realizowanej przez odmienne typy podmiotów; jak również poddanie dyskusji poglądów dotyczących przebiegu i efektów uczenia się i nabywania kompetencji kulturalnych w dorosłości.

Książka ma logiczną i przemyślaną strukturę. Podzielona została na trzy części, poprzedzone wprowadzeniem, w którym autorki formułują cele rozważań, osadzają je w kontekście społeczno-kulturowym i politycznym oraz wskazują na podstawy empiryczne i teoretyczne książki.

Pierwszą część pracy poświęcono strukturom oraz znaczeniu edukacji kulturalnej dorosłych. W otwierającym ją rozdziale badaczki koncentrują się na podmiotach realizujących w Niemczech edukację kulturalną dorosłych, profilach, programach oraz przestrzeniach, w których jest ona przeprowadzana. Przedstawiono tu, po pierwsze, edukację kulturalną oferowaną przez publiczne instytucje edukacji dorosłych, (np. uniwersytety ludowe, podmioty związane z kościołem); po drugie, instytucje (głównie kultury) i organizacje, dla których edukacja kulturalna dorosłych stanowi zadanie dodatkowe (beigeordnete kulturelle Bildung); po trzecie, instytucje oferujące doskonale- 
nie zawodowe w zakresie prowadzenia edukacji kulturalnej dla twórców kultury i sztuki, a po czwarte - struktury działające w ramach projektów. Zgodnie z założeniem, że edukacja kulturalna nie jest niezależna od aktualnego kontekstu społecznego i wyraża ducha czasu, w drugim rozdziale książki zarysowano zjawisko nowego zainteresowania edukacją kulturalną ze strony polityki oświatowej oraz biznesu, rosnące w siłę mniej więcej od roku 2000. Tę część pracy kończy rozdział trzeci kreślący obraz edukacji kulturalnej na podstawie danych zaczerpniętych z najnowszych studiów o charakterze monitoringu edukacji.

W drugiej części książki Fleige, Gieseke oraz Robak w centrum rozważań sytuują uczestników edukacji kulturalnej oraz jej tematykę. Rozpoczynający tę część rozdział czwarty prezentuje kwestie zainteresowania edukacją, procesów uczenia się i ich przebiegu w przestrzeni edukacji kulturalnej w świetle podejść pedagogicznych, filozoficznych, kulturoznawczych, antropologicznych. W dalszej kolejności (rozdział 5) opisano tematykę i realizowane w praktyce koncepcje edukacji kulturalnej dorosłych, jak również zarysowano aktualne tendencje w tym obszarze.

Trzecia cześć recenzowanej monografii to prezentacja, wypracowanej na podstawie rozpoznań empirycznych i w powiązaniu z interdyscyplinarnymi kontekstami teoretycznymi, teorii edukacji kulturalnej dorosłych, której fundament stanowi koncepcja portali uczestnictwa w edukacji kulturalnej dorosłych. W trzech kolejnych rozdziałach (szóstym, siódmym i ósmym) autorki przedstawiają zatem portal receptywno-systematyczny, portal własnej aktywności twórczej oraz rozumiejąco-komunikacyjny/interkulturowy, pokazując także, w jakich dziedzinach kultury tak ujęta edukacja kulturalna się realizuje i jak w nich przebiega.

W ostatnim, podsumowującym rozdziale rozważań autorki formułują tezy końcowe i pytania, przed którymi stają dziś zarówno praktycy, jak i badacze edukacji kulturalnej dorosłych, zarysowują także związane z tymi wyzwaniami perspektywy badań omawianego obszaru.

Bez wątpienia recenzowana książka w znaczącym stopniu wzbogaca wiedzę o edukacji kulturalnej dorosłych i stanowi cenny wkład w refleksję naukową na ten temat. Wartość tej monografii polega nie tylko na tym, iż przedstawia ona aktualne trendy w edukacji kulturalnej dorosłych w oparciu o dane empiryczne $z$ ostatnich lat, ale stanowi też dojrzałą i oryginalną próbę stworzenia koncepcji edukacji kulturalnej dorosłych. Autorki tę sferę edukacji dorosłych lokują w szerokim interdyscyplinarnym kontekście teoretycznym i jednocześnie osadzają ją na tle uwarunkowań społeczno-kulturowych i politycznych. Co ważne, recenzowana praca proponuje okre- 
ślony sposób pojmowania edukacji kulturalnej, traktując ją jako sferę praktyki edukacyjnej pozwalającą jednostce odnaleźć orientację we współczesnej zmiennej rzeczywistości, a w szerszym wymiarze wspierającą rozwój demokracji. Ponadto autorki, uwzględniając dokonujące się obecnie głębokie przeobrażenia rzeczywistości społeczno-kulturowej, stawiają wiele ważnych pytań odnośnie do edukacji kulturalnej dorosłych, które mogą być szczególnie interesujące i inspirujące dla czytelnika zainteresowanego naukowo tym obszarem edukacji dorosłych.

Sylwia Słowińska 